\title{
Effect of Apolipoprotein E $\varepsilon 4$ on the association between health behaviors and cognitive function in late midlife
}

\author{
Séverine Sabia*1, Mika Kivimaki2, Meena Kumari2, Martin J Shipley² and Archana Singh-Manoux¹,2,3
}

\begin{abstract}
The extent to which the effect of risk factors on cognitive ageing is dependent on APOE $\varepsilon 4$ remains unclear. The objective of this study is to examine whether APOE $\varepsilon 4$ allele modifies the association between health behaviors and cognition in late midlife. Data are drawn from 5447 participants of the Whitehall II study, health behaviors were assessed in 1997-1999 (mean age $=55.6$, Standard Deviation $(S D)=6.0$ ) and APOE genotype and cognitive function in 2002-2004 (mean age $=60.9, \mathrm{SD}=5.9$ ). Among APOE $\varepsilon 4$ non-carriers, current smokers had lower scores on memory (difference in T-score $=-2.49,95 \% \mathrm{Cl}:-3.37,-1.60)$, reasoning $(-2.88,95 \% \mathrm{Cl}:-3.74,-2.01)$, phonemic $(-2.66,95 \% \mathrm{Cl}:-3.56$, 1.76) and semantic (-2.38, 95\%Cl: $-3.28,-1.47)$ fluency compared to never smokers. In APOE $\varepsilon 4$ carriers, difference between current and never smokers was seen only for reasoning $(-1.92,95 \% \mathrm{Cl}:-3.31,-0.51)$. Interaction terms supported differential effects of smoking as a function of APOE $\varepsilon 4$ status for memory $(p=0.01)$, and phonemic $(p=$ $0.008)$ and semantic fluency $(p=0.02)$. Cognitive scores were lower among non-drinkers compared to moderate drinkers, among the sedentary participants and those who ate fruits and vegetable less than 2 times per day irrespective of APOE $\varepsilon 4$ status. This study suggests that the APOE $\varepsilon 4$ allele modifies the association of smoking but not that of other health behaviors - alcohol consumption, physical activity, fruit and vegetable consumption - with cognitive function in late midlife.
\end{abstract}

\section{Findings}

Carriers of the apolipoprotein E (APOE) $\varepsilon 4$ allele are at increased risk of late onset Alzheimer's disease [1]. Among APOE $\varepsilon 4$ carriers there is evidence of atypical brain activity in young adulthood [2] and greater cognitive decline in middle-age [3,4]. Recently, it has been suggested that, in addition to these direct associations, APOE $\varepsilon 4$ might also influence cognition indirectly by modifying the effect of non-genetic risk factors, such as health behaviors, on cognitive ageing [5,6]. Indeed, adverse health behaviors are risk factors for impaired cognition and dementia [5,7]; however, a recent review concluded that more research is needed to confirm or refute the hypothesis of a differential effect of health behaviors among APOE $\varepsilon 4$ carriers [7]. Thus, the objective of the present study is to examine whether APOE $\varepsilon 4$

*Correspondence: severine.sabia@inserm.fr

1 INSERM, U1018 Centre for Research in Epidemiology \& Population Health, Hopital Paul Brousse, 16 avenue Paul Vaillant Couturier, Bâtiment 15/16, F94807, Villejuif, France

Full list of author information is available at the end of the article allele modifies the association of smoking, alcohol consumption, physical activity and dietary behavior with cognitive function in late midlife.

Data are drawn from the Whitehall II study, established in 1985 on 10308 British civil servants (6895 men and 3413 women) [8]. The University College London ethics committee approved the study and all participants gave written consent to participate in the study. The study population for the present analysis is composed of 5447 participants with complete data on health behaviors assessed during 1997-1999 (wave 5 of the study, mean age $=55.6$, Standard Deviation $(\mathrm{SD})=6.0)$ and APOE genotype and cognitive function assessed during 2002-2004 (wave 7 of the study, mean age $=60.9(\mathrm{SD}=5.9)$ ).

APOE genotype Two TaqMan assays (Rs429358 and Rs7412, Assay-On-Demand, Applied Biosystems) were used and run on a 7900HT analyzer (Applied Biosystems), and genotypes indicated by the Sequence Detection Software version 2.0 (Applied Biosystems). Each SNP was found to be within Hardy Weinberg Equilibrium ( $\mathrm{x} 2$ 
$\mathrm{p}>0.4)$. Genotyping was repeated for 511 participants and error rates were found to be $<0.15 \%$. APOE $\varepsilon 2 / \varepsilon 3 / \varepsilon 4$ haplotypes were created and participants were categorized as APOE \&4 non-carriers and APOE $\varepsilon 4$ carriers for those with at least one $\varepsilon 4$ allele.

Health behaviors were assessed via questionnaire Smoking status was assessed using questions on current and past smoking and categorized as never, past and current smokers. Alcohol consumption was assessed via questions on the number of alcoholic drinks ("measures" of spirits, "glasses" of wine, and "pints" of beer) consumed in the last seven days, converted to number of units of alcohol with each unit corresponding to 8 grams of ethanol. Alcohol consumption was categorized as: abstinence (none), moderate (1-14 units/week for women and 1-21 units/week for men), and high consumption (15 or more units/week in women and 22 or more in men). Physical activity questionnaire included 20 items on frequency and duration of participation in different physical activities (e.g. walking, sports, and gardening) that were used to compute hours per week of moderate and vigorous physical activity. This information was used to identify those with sedentary habit, defined as less than one hour per week of moderate physical activity and less than one hour per week of vigorous physical activity. Dietary behavior was assessed using a measure of frequency of fruit and vegetable consumption with the question "How often do you eat fresh fruit or vegetables?"; responses were on an eight-point scale, ranging from 'seldom or never' to 'two or more times a day'.

Cognitive function was measured with multiple tests Short-term verbal memory was assessed with a 20-word free recall test. Participants were presented a list of 20 one or two syllable words at two second intervals and then had two minutes to recall in writing as many of the words in any order. The AH4-I (Alice Heim 4-I) was used to assess reasoning. This test is composed of a series of 65 verbal and mathematical reasoning items of increasing difficulty [9]. It tests inductive reasoning, measuring the ability to identify patterns and infer principles and rules. Participants had 10 minutes to do this section. We used two measures of verbal fluency: phonemic and semantic [10]. Phonemic fluency was assessed via "S" words and semantic fluency via "animal" words. Subjects were asked to write as many words beginning with "S" and as many animal names as they could. One minute was allowed for each fluency test.

Covariates in the analysis, assessed alongside the health behaviors, were sex, age, socioeconomic position indexed as 6-level British civil service employment grade [8], and education (no or lower primary school, lower secondary school, higher secondary school, university, and higher university degree).
All cognitive scores were standardized to T-scores which are similar to $\mathrm{z}$-scores but have a mean of 50 and a SD of 10 in order to allow comparison between tests. The association between categories of health behaviors and cognitive T-scores was examined using analysis of covariance (ANCOVA). The difference in mean cognitive $\mathrm{T}$ score, as well as the $95 \%$ confidence intervals (CI), adjusted for age and sex, was calculated across health behavior categories separately for APOE $\varepsilon 4$ non-carriers and carriers. In order to examine whether the APOE $\varepsilon 4$ allele modifies the association between health behaviors and each cognitive measure, an interaction term between APOE $\varepsilon 4$ status and health behavior categories was included in the model containing the main effects, separately for each health behavior. We also used multiple analysis of covariance (MANCOVA) to assess the overall interaction between each health behavior and APOE $\varepsilon 4$ status for all cognitive measures considered together. The use of MANCOVA serves two purposes; it takes the correlation between the cognitive tests into account and provides a $p$ value for the overall interaction term [11]. This method reduces the likelihood of Type I error, common when multiple outcomes are analysed separately. Finally, in order to examine whether the results were robust to the effects of socioeconomic position, all analyses were repeated with additional adjustment for employment grade and education.

Table 1 presents the characteristics of the participants as a function of their APOE \&4 status. Among the 3929 non-carriers, $14.9 \%$ were smokers, $12.5 \%$ were alcohol abstainers, $26.4 \%$ were sedentary, and $39.6 \%$ ate fruit and vegetables less than 2 times per day. The corresponding figures among the 1518 APOE $\varepsilon 4$ carriers were no different, $14.6 \%, 14.1 \%, 25.7 \%$, and $41.5 \%$, respectively.

The associations between health behaviors in 19971999 and cognitive function in 2002-2004 as a function of the APOE $\varepsilon 4$ allele are presented in Table 2. Among the APOE $\varepsilon 4$ non-carriers, current smokers had lower scores on memory (difference in T-score $=-2.49,95 \% \mathrm{CI}$ : -3.37 , $1.60)$, reasoning $(-2.88,95 \% \mathrm{CI}:-3.74,-2.01)$, phonemic (2.66, 95\%CI: $-3.56,-1.76)$ and semantic $(-2.38,95 \% \mathrm{CI}$ : $3.28,-1.47)$ fluency compared to never smokers. In the APOE $\varepsilon 4$ carriers, a corresponding difference between current and never smokers was only seen for reasoning (1.92, 95\%CI: $-3.31,-0.51)$. Interaction terms for memory $(p=0.01)$, phonemic $(p=0.008)$ and semantic fluency ( $p$ $=0.02$ ) supported differential effects of smoking as a function of APOE $\varepsilon 4$ status. Compared to never smokers, ex-smokers had on average better scores in phonemic $(+1.35,95 \% \mathrm{CI}: 0.27,2.42)$ and semantic $(+1.27,95 \% \mathrm{CI}$ : $0.25,2.30)$ fluency among the APOE $\varepsilon 4$ carriers but not among the non-carriers ( $p$ for interaction $=0.04$ and 0.006 , respectively). MANCOVA also suggested an over- 
Table 1: Characteristics of the study population.

\begin{tabular}{|c|c|c|}
\hline & APOE $\varepsilon 4$ non-carriers & APOE $\varepsilon 4$ carriers \\
\hline $\mathrm{N}$ & 3929 & 1518 \\
\hline Age $(M, S D)$ & $60.9(5.9)$ & $60.8(5.9)$ \\
\hline Women $(\mathrm{N}, \%)$ & $1071(27.3)$ & $384(25.3)$ \\
\hline Lower employment grade (N, \%) & $839(21.4)$ & $312(20.6)$ \\
\hline Less than secondary school (N, \%) & $1641(41.8)$ & $634(41.8)$ \\
\hline \multicolumn{3}{|l|}{ Smoking status (N, \%) } \\
\hline Current & $587(14.9 \%)$ & $221(14.6 \%)$ \\
\hline Past & $1468(37.4 \%)$ & $560(36.9 \%)$ \\
\hline Never & $1874(47.7 \%)$ & $737(48.6 \%)$ \\
\hline \multicolumn{3}{|l|}{ Alcohol consumption ( $\mathrm{N}, \%)$} \\
\hline Abstinence & $490(12.5 \%)$ & $214(14.1 \%)$ \\
\hline Moderate & $2016(51.3 \%)$ & $749(49.3 \%)$ \\
\hline High & $1423(36.2 \%)$ & $555(36.6 \%)$ \\
\hline \multicolumn{3}{|l|}{ Sedentary habit $(\mathrm{N}, \%)$} \\
\hline Yes & 1039 (26.4\%) & $390(25.7 \%)$ \\
\hline No & $2890(73.6 \%)$ & $1128(74.3 \%)$ \\
\hline \multicolumn{3}{|c|}{$\begin{array}{l}\text { Fruit \& vegetable consumption less } \\
\text { than } 2 \text { times/day }(\mathrm{N}, \%)\end{array}$} \\
\hline Yes & $1555(39,6 \%)$ & $630(41,5 \%)$ \\
\hline No & $2374(60,4 \%)$ & $888(58,5 \%)$ \\
\hline
\end{tabular}

all interaction between APOE $\varepsilon 4$ status and both current $(p=0.04)$ and past smoking $(p=0.02)$.

Cognitive scores were lower among non-drinkers compared to moderate drinkers, among the sedentary participants and those who ate fruit and vegetables less than 2 times per day. These associations were present in both APOE $\varepsilon 4$ non-carriers and carriers with no evidence of differential effects as a function of the APOE $\varepsilon 4$ status $(p$ for interaction from MANCOVA was 0.37 for alcohol abstinence, 0.31 for high alcohol consumption, 0.70 for sedentary habit, and 0.69 for fruit and vegetable consumption). In models further adjusted for employment grade and education (Table 3 ), the effect sizes were somewhat attenuated in both APOE $\varepsilon 4$ carriers and non-carriers. However, the interaction terms remain unchanged except that for past smoking.
These prospective data from over five thousand British adults suggest that the APOE $\varepsilon 4$ allele modifies the impact of smoking but not that of other health behaviors - alcohol consumption, physical activity, fruit and vegetable consumption - on cognitive function in late midlife. Among the APOE $\varepsilon 4$ non-carriers, current smokers had lower scores on multiple cognitive tests, such as memory, phonemic and semantic fluency, compared with never smokers. A corresponding pattern was not observed among the APOE $\varepsilon 4$ carriers.

Our findings are in agreement with previous studies on clinical outcomes which documented evidence of an interaction between APOE $\varepsilon 4$ and current smoking. In those studies, a higher risk of dementia among smokers was found, but only among APOE $\varepsilon 4$ non-carriers [1216]. We also observed higher cognitive scores among ex- 
Table 2: Association between health behaviors and cognitive function as a function of APOE $\varepsilon 4$ status adjusted for socioeconomic variables.

\begin{tabular}{|c|c|c|c|c|c|}
\hline \multirow[b]{2}{*}{ Health behaviors } & Memory & Reasoning & Phonemic fluency & Semantic fluency & \multirow[t]{2}{*}{$\begin{array}{c}p \text { for } \\
\text { interaction }\end{array}$} \\
\hline & Difference† $(95 \% \mathrm{Cl})$ & Difference† (95\% CI) & Differencet $(95 \% \mathrm{Cl})$ & Differencet $(95 \% \mathrm{Cl})$ & \\
\hline \multicolumn{6}{|l|}{ Current smoking ${ }^{\S}$} \\
\hline APOE $\varepsilon 4$ non-carriers & $-2.49(-3.37,-1.60)^{*}$ & $-2.88(-3.74,-2.01)^{*}$ & $-2.66(-3.56,-1.76)^{*}$ & $-2.38(-3.28,-1.47)^{*}$ & \\
\hline APOE $\varepsilon 4$ carriers & $-0.34(-1.79,1.11)$ & $-1.92(-3.31,-0.51)^{*}$ & $-0.35(-1.82,1.11)$ & $-0.34(-1.74,1.06)$ & \\
\hline$p$ for interaction & 0.01 & 0.24 & 0.008 & 0.02 & 0.04 \\
\hline \multicolumn{6}{|l|}{ Past smoking ${ }^{\S}$} \\
\hline APOE $\varepsilon 4$ non-carriers & $-0.21(-0.89,0.44)$ & $-0.44(-1.08,0.20)$ & $0.05(-0.62,0.72)$ & $-0.39(-1.06,0.28)$ & \\
\hline APOE $\varepsilon 4$ carriers & $0.71(-0.35,1.78)$ & $0.08(-0.95,1.11)$ & $1.35(0.27,2.42)^{*}$ & $1.27(0.25,2.30)^{*}$ & \\
\hline$p$ for interaction & 0.11 & 0.36 & 0.04 & 0.006 & 0.02 \\
\hline \multicolumn{6}{|l|}{ Alcohol abstinence } \\
\hline APOE $\varepsilon 4$ non-carriers & $-1.24(-2.18,-0.30)^{*}$ & $-3.80(-4.71,-2.90)^{*}$ & $-3.05(-4.00,-2.10)^{*}$ & $-2.57(-3.52,-1.61)^{*}$ & \\
\hline APOE $\varepsilon 4$ carriers & $-2.16(-3.62,-0.71)^{*}$ & $-3.04(-4.44,-1.63)^{*}$ & $-2.88(-4.34,-1.41)^{*}$ & $-3.06(-4.46,-1.66)^{*}$ & \\
\hline$p$ for interaction & 0.22 & 0.43 & 0.88 & 0.48 & 0.37 \\
\hline \multicolumn{6}{|l|}{$\begin{array}{l}\text { High alcohol } \\
\text { consumption" }\end{array}$} \\
\hline APOE $\varepsilon 4$ non-carriers & $0.63(-0.08,1.34)$ & $1.15(0.47,1.84)^{*}$ & $1.13(0.41,1.85)^{*}$ & $1.19(0.47,1.91)^{*}$ & \\
\hline APOE $\varepsilon 4$ carriers & $1.19(0.05,2.32)^{*}$ & $0.90(-0.19,1.99)$ & $1.96(0.82,3.10)^{*}$ & $0.77(-0.33,1.86)$ & \\
\hline$p$ for interaction & 0.39 & 0.73 & 0.23 & 0.55 & 0.31 \\
\hline \multicolumn{6}{|l|}{ Sedentary habit ${ }^{* *}$} \\
\hline APOE $\varepsilon 4$ non-carriers & $-0.90(-1.55,-0.20)^{*}$ & $-1.20(-1.90,-0.50)^{*}$ & $-1.50(-2.23,-0.80)^{*}$ & $-1.50(-2.18,-0.80)^{*}$ & \\
\hline APOE $\varepsilon 4$ carriers & $-0.60(-1.73,0.53)$ & $-1.30(-2.43,-0.30)^{*}$ & $-1.30(-2.46,-0.20)^{*}$ & $-2.00(-3.12,-1.00)^{*}$ & \\
\hline$p$ for interaction & 0.92 & 0.72 & 0.90 & 0.25 & 0.70 \\
\hline \multicolumn{6}{|c|}{$\begin{array}{l}\text { Fruit \& vegetable } \\
\text { consumption less than } \\
2 \text { times/dayt+ }\end{array}$} \\
\hline APOE $\varepsilon 4$ non-carriers & $-1.50(-2.15,-0.90)^{*}$ & $-3.20(-3.83,-2.60)^{*}$ & $-2.10(-2.75,-1.50)^{*}$ & $-3.10(-3.73,-2.50)^{*}$ & \\
\hline APOE $\varepsilon 4$ carriers & $-1.20(-2.16,-0.20)^{*}$ & $-3.00(-3.92,-2.00)^{*}$ & $-1.30(-2.29,-0.30)^{*}$ & $-2.70(-3.67,-1.80)^{*}$ & \\
\hline$p$ for interaction & 0.45 & 0.59 & 0.15 & 0.46 & 0.69 \\
\hline
\end{tabular}

smokers compared to never smokers among the APOE $\varepsilon 4$ carriers. A previous study reported similar results for the risk of Alzheimer's disease [12]. However, in our analysis the effect of past smoking, compared with never smoking, did not differ as a function of APOE $\varepsilon 4$ status when socio-economic position was taken into account. Thus, the higher scores among the ex-smokers who were APOE $\varepsilon 4$ carriers compared to APOE $\varepsilon 4$ non-carriers appeared to be due to confounding by socioeconomic factors. It is plausible that the effects of smoking in APOE $\varepsilon 4$ carriers are attenuated as these individuals have been shown to have fewer nicotinic receptor binding sites and lower activity of choline acetyltransferase than non carriers [17]. Smoking might counterbalance the deficit in nic- 
Table 3: Association between health behaviors and cognitive function as a function of APOE $\varepsilon 4$ status adjusted for socioeconomic variables.

\begin{tabular}{|c|c|c|c|c|c|}
\hline & Memory & Reasoning & Phonemic fluency & Semantic fluency & $p$ for interaction $\neq$ \\
\hline Health behaviors & Differencet $(95 \% \mathrm{Cl})$ & Differencet $(95 \% \mathrm{CI})$ & Differencet $(95 \% \mathrm{Cl})$ & Differencet $(95 \% \mathrm{Cl})$ & \\
\hline \multicolumn{6}{|l|}{ Current smoking ${ }^{\S}$} \\
\hline APOE $\varepsilon 4$ non-carriers & $-1.65(-2.53,-0.79)^{*}$ & $-1.10(-1.84,-0.36)^{*}$ & $-1.46(-2.32-0.61)^{*}$ & $-0.99(-1.83,-0.14)^{*}$ & \\
\hline APOE $\varepsilon 4$ carriers & $0.41(-1.02,1.84)$ & $-0.36(-1.59,0.86)$ & $0.73(-0.67,2.12)$ & $0.88(-0.42,2.17)$ & \\
\hline$p$ for interaction & 0.01 & 0.27 & 0.009 & 0.02 & 0.02 \\
\hline \multicolumn{6}{|l|}{ Past smoking $\S$} \\
\hline APOE ع4 non-carriers & $0.17(-0.47,0.82)$ & $0.28(-0.26,0.83)$ & $0.56(-0.07,1.19)$ & $0.19(-0.42,0.82)$ & \\
\hline APOE $\varepsilon 4$ carriers & $0.76(-0.28,1.80)$ & $0.15(-0.75,1.04)$ & $1.40(0.38,2.42)^{*}$ & $1.30(0.35,2.25)^{*}$ & \\
\hline$p$ for interaction & 0.30 & 0.68 & 0.22 & 0.06 & 0.17 \\
\hline \multicolumn{6}{|l|}{ Alcohol abstinence } \\
\hline APOE ع4 non-carriers & $-0.12(-1.06,0.81)$ & $-1.07(-1.86,-0.28)^{*}$ & $-1.21(-2.13,-0.30)^{*}$ & $-0.51(-1.40,0.39)$ & \\
\hline APOE $\varepsilon 4$ carriers & $-1.56(-3.00,-0.12)^{*}$ & $-1.65(-2.88,-0.42)^{*}$ & $-2.00(-3.40,-0.59)^{*}$ & $-1.97(-3.28,-0.66)^{*}$ & \\
\hline$p$ for interaction & 0.08 & 0.67 & 0.58 & 0.09 & 0.28 \\
\hline \multicolumn{6}{|l|}{$\begin{array}{l}\text { High alcohol } \\
\text { consumption }\end{array}$} \\
\hline APOE $\varepsilon 4$ non-carriers & $0.25(-0.45,0.94)$ & $0.33(-0.26,0.91)$ & $0.55(-0.13,1.23)$ & $0.53(-0.14,1.20)$ & \\
\hline APOE $\varepsilon 4$ carriers & $0.91(-0.20,2.03)$ & $0.16(-0.80,1.11)$ & $1.49(0.40,2.58)^{*}$ & $0.15(-0.86,1.17)$ & \\
\hline$p$ for interaction & 0.37 & 0.62 & 0.23 & 0.48 & 0.30 \\
\hline \multicolumn{6}{|l|}{ Sedentary habit ${ }^{* *}$} \\
\hline APOE $\varepsilon 4$ non-carriers & $-0.37(-1.05,0.32)$ & $0.06(-0.52,0.64)$ & $-0.66(-1.33,-0.00)^{*}$ & $-0.52(-1.18,0.14)$ & \\
\hline APOE $\varepsilon 4$ carriers & $-0.03(-1.15,1.09)$ & $-0.08(-1.03,0.88)$ & $-0.52(-1.61,0.57)$ & $-1.14(-2.15,-0.12)^{*}$ & \\
\hline p for interaction & 0.81 & 0.88 & 0.64 & 0.35 & 0.71 \\
\hline \multicolumn{6}{|l|}{$\begin{array}{l}\text { Fruit \& vegetable } \\
\text { consumption less } \\
\text { than } 2 \text { times/dayt+ }\end{array}$} \\
\hline APOE $\varepsilon 4$ non-carriers & $-0.60(-1.22,0.01)$ & $-1.12(-1.65,-0.60)^{*}$ & $-0.65(-1.26,-0.05)^{*}$ & $-1.49(-2.08,-0.90)^{*}$ & \\
\hline APOE $\varepsilon 4$ carriers & $-0.49(-1.47,0.50)$ & $-1.43(-2.27,-0.59)^{*}$ & $-0.19(-1.16,0.77)$ & $-1.53(-2.43,-0.64)^{*}$ & \\
\hline$p$ for interaction & 0.70 & 0.74 & 0.37 & 0.94 & 0.82 \\
\hline
\end{tabular}

otine receptors and the lack of acetylcholine found in APOE $\varepsilon 4$ carriers $[14,18]$. Another possible mechanism behind the smaller impact of smoking in APOE $\varepsilon 4$ carriers relates to several processes associated with the APOE $\varepsilon 4$ allele that accelerate degenerative changes in arteries and brain, such as a somewhat higher total blood cholesterol, more oxidized blood lipids, and greater risk of coronary heart disease $[2,19,20]$. Such genetic influences may reduce the relative importance of other risk factors for cognitive ageing, such as smoking. Given this, it is surprising that there was no clear evidence of effect modification by APOE $\varepsilon 4$ on the association between other health behaviors and cognition. Our results confirm previous studies suggesting that the effect of health behaviors on cognition does not differ by APOE $\varepsilon 4$ status for alcohol [21-23], physical activity [21,24,25], or diet [26].

The strengths of this study include a detailed assessment of health behaviors and a large battery of cognitive 
tests covering multiple cognitive domains. However, although our sample covered a wide socioeconomic range, with annual full-time salaries ranging from $£ 4,995$ to $£ 150,000$, the data are exclusively from white-collar civil servants and cannot therefore be assumed to be representative of the general population. The use of multiple testing increases the risk of Type 1 error and in order to ensure the robustness of our findings we repeated the analyses using MANCOVA to obtain an overall interaction term. The conclusions were similar from both analyses. In conclusion, this study suggests that smoking is associated with lower cognitive function only among APOE $\varepsilon 4$ non-carriers. Presence of the APOE $\varepsilon 4$ allele did not modify the impact of other health behaviors on cognition.

\section{List of abbreviations}

APOE: Apolipoprotein E; ANCOVA: analysis of covariance; MANCOVA: multiple analysis of covariance; AH4I: Alice Heim 4-I

\section{Conflict of interests}

The authors declare that they have no competing interests.

\begin{abstract}
Authors' contributions
SS analysed the data and wrote the first full draft of the paper. All authors jointly designed the hypothesis, interpreted the data and edited the paper. SS had full access to all of the data in the study and takes responsibility for the integrity of the data and the accuracy of the data analysis. All authors read and approved the final manuscript.
\end{abstract}

\section{Acknowledgements \\ ASM is supported by a "European Young Investigator Award" from the Euro- pean Science Foundation and MK by the BUPA Foundation and the Academy of Finland. The Whitehall II study has been supported by grants from the British Medical Research Council (MRC); the British Heart Foundation; the British Health and Safety Executive; the British Department of Health; the National Heart, Lung, and Blood Institute, NIH (R01HL036310); the National Institute on Aging, NIH (R01AG013196; R01AG034454). The funding bodies did not partici- pate in the study design, analysis or interpretation of data, or manuscript prep- aration. \\ We thank all of the participating civil service departments and their welfare, personnel, and establishment officers; the British Occupational Health and Safety Agency; the British Council of Civil Service Unions; all participating civil servants in the Whitehall II study; and all members of the Whitehall II study team.}

\section{Author Details \\ IINSERM, U1018 Centre for Research in Epidemiology \& Population Health, Hopital Paul Brousse, 16 avenue Paul Vaillant Couturier, Bâtiment 15/16, F- 94807, Villejuif, France, 2Department of Epidemiology and Public Health, University College London, UK and ${ }^{3}$ Centre de Gérontologie, Hôpital Ste Perine, AP-HP, Paris, France}

Received: 2 April 2010 Accepted: 1 June 2010

Published: 1 June 2010

\section{References}

1. Bookheimer S, Burggren A: APOE-4 genotype and neurophysiological vulnerability to Alzheimer's and cognitive aging. Annu Rev Clin Psychol 2009, 5:343-362.
2. Filippini N, MacIntosh BJ, Hough MG, Goodwin GM, Frisoni GB, Smith SM Matthews PM, Beckmann CF, Mackay CE: Distinct patterns of brain activity in young carriers of the APOE-epsilon4 allele. Proc Natl Acad Sci USA 2009, 106:7209-7214.

3. Caselli RJ, Dueck AC, Osborne D, Sabbagh MN, Connor DJ, Ahern GL, Baxter LC, Rapcsak SZ, Shi J, Woodruff BK, et al.: Longitudinal modeling of age-related memory decline and the APOE epsilon4 effect. N Engl J Med 2009, 361:255-263.

4. Knopman DS, Mosley TH, Catellier DJ, Coker LH: Fourteen-year longitudinal study of vascular risk factors, APOE genotype, and cognition: the ARIC MRI Study. Alzheimers Dement 2009, 5:207-214.

5. Kivipelto M, Rovio S, Ngandu T, Kareholt I, Eskelinen M, Winblad B, Hachinski V, Cedazo-Minguez A, Soininen H, Tuomilehto J, et al:: Apolipoprotein E epsilon4 Magnifies Lifestyle Risks for Dementia: A Population Based Study. J Cell Mol Med 2008, 12:2762-2771.

6. Sabia S, Nabi H, Kivimaki M, Shipley MJ, Marmot MG, Singh-Manoux A: Health behaviors from early to late midlife as predictors of cognitive function: The Whitehall II study. Am J Epidemiol 2009, 170:428-437.

7. Low LF, Yap MH, Brodaty $\mathrm{H}$ : Will testing for apolipoprotein $\mathrm{E}$ assist in tailoring dementia risk reduction? A review. Neurosci Biobehav Rev 2010, 34:408-437.

8. Marmot MG, Smith GD, Stansfeld S, Patel C, North F, Head J, White I, Brunner E, Feeney A: Health inequalities among British civil servants: the Whitehall II study. Lancet 1991, 337:1387-1393.

9. Heim AW: AH 4 group test of general Intelligence. Windsor, UK: NFERNelson Publishing Company Ltd; 1970.

10. Borkowski JG, Benton AL, Spreen O: Word fluency and brain damage. Neuropsychologica 1967, 5:135-140.

11. Hair JF, Anderson RE, Tatham RL, Black WC: Multivariate Analysis of Variance. In Multivariate data Analysis fifth edition. Prentice Hall International Editions; 1998:326-386

12. Aggarwal NT, Bienias JL, Bennett DA, Wilson RS, Morris MC, Schneider JA, Shah RC, Evans DA: The relation of cigarette smoking to incident Alzheimer's disease in a biracial urban community population. Neuroepidemiology 2006, 26:140-146.

13. Merchant C, Tang MX, Albert S, Manly J, Stern Y, Mayeux R: The influence of smoking on the risk of Alzheimer's disease. Neurology 1999, 52:1408-1412

14. Ott A, Slooter AJ, Hofman A, van HF, Witteman JC, Van BC, van Duijn CM, Breteler MM: Smoking and risk of dementia and Alzheimer's disease in a population-based cohort study: the Rotterdam Study. Lancet 1998, 351:1840-1843.

15. Reitz C, den HT, van DC, Hofman A, Breteler MM: Relation between smoking and risk of dementia and Alzheimer disease: the Rotterdam Study. Neurology 2007, 69:998-1005.

16. Tyas SL, White LR, Petrovitch H, Webster RG, Foley DJ, Heimovitz HK, Launer $\sqcup$ : Mid-life smoking and late-life dementia: the Honolulu-Asia Aging Study. Neurobiol Aging 2003, 24:589-596.

17. Poirier J, Delisle MC, Quirion R, Aubert I, Farlow M, Lahiri D, Hui S, Bertrand P, Nalbantoglu J, Gilfix BM, et al:: Apolipoprotein E4 allele as a predictor of cholinergic deficits and treatment outcome in Alzheimer disease. Proc Natl Acad Sci USA 1995, 92:12260-12264.

18. van Duijn CM, Havekes LM, Van BC, de KP, Hofman A: Apolipoprotein $E$ genotype and association between smoking and early onset Alzheimer's disease. BMJ 1995, 310:627-631.

19. Mahley RW: Apolipoprotein E: cholesterol transport protein with expanding role in cell biology. Science 1988, 240:622-630.

20. Wilson PW, Schaefer EJ, Larson MG, Ordovas JM: Apolipoprotein E alleles and risk of coronary disease. A meta-analysis. Arterioscler Thromb Vasc Biol 1996, 16:1250-1255.

21. Lindsay J, Laurin D, Verreault R, Hebert R, Helliwell B, Hill GB, McDowell I: Risk factors for Alzheimer's disease: a prospective analysis from the Canadian Study of Health and Aging. Am J Epidemiol 2002, 156:445-453.

22. Ruitenberg A, van Swieten JC, Witteman JC, Mehta KM, van Duijn CM, Hofman A, Breteler MM: Alcohol consumption and risk of dementia: the Rotterdam Study. Lancet 2002, 359:281-286.

23. Tanaka N, Asada T, Kinoshita T, Yamashita F, Uno M: Alcohol consumption and risk of dementia. Lancet 2002, 360:491.

24. Rovio S, Kareholt I, Viitanen M, Winblad B, Tuomilehto J, Soininen $H$, Nissinen A, Kivipelto M: Work-related physical activity and the risk of 
dementia and Alzheimer's disease. Int $J$ Geriatr Psychiatry 2007, 22:874-882.

25. Taaffe DR, Irie F, Masaki KH, Abbott RD, Petrovitch H, Ross GW, White LR: Physical activity, physical function, and incident dementia in elderly men: the Honolulu-Asia Aging Study. J Gerontol A Biol Sci Med Sci 2008 63:529-535.

26. Laurin D, Masaki KH, Foley DJ, White LR, Launer LJ: Midlife dietary intake of antioxidants and risk of late-life incident dementia: the HonoluluAsia Aging Study. Am J Epidemiol 2004, 159:959-967.

doi: 10.1186/1750-1326-5-23

Cite this article as: Sabia et al., Effect of Apolipoprotein E ?4 on the association between health behaviors and cognitive function in late midlife $\mathrm{Molecu}$ lar Neurodegeneration 2010, 5:23

Submit your next manuscript to BioMed Central and take full advantage of:

- Convenient online submission

- Thorough peer review

- No space constraints or color figure charges

- Immediate publication on acceptance

- Inclusion in PubMed, CAS, Scopus and Google Scholar

- Research which is freely available for redistribution

Submit your manuscript at www.biomedcentral.com/submit
C) Biomed Central 